\title{
The effect of nitrogen application and various means of weed control on grain yield, protein and lipid content in soybean cultivation
}

\author{
R. Abd Ghani* (), Z. Kende, Á. Tarnawa, S. Omar, M.K. Kassai and M. Jolánkai
}

Department of Agronomy, Hungarian University of Agriculture and Life Sciences, H-2100 Gödöllö, Páter Károly u. 1, Hungary

\section{ORIGINAL RESEARCH PAPER}

Received: April 10, 2021 • Accepted: June 29, 2021

Published online: August 30, 2021

(c) 2021 The Author(s)

\section{ABSTRACT}

Soybean is one of the most important leguminous crops that contributes to human alimentation and animal feed. Soybean grain with its high protein and valuable lipid content is an essential component for the food and feed industries worldwide. Apart from the genetically determined quality characteristics of a certain variety, management practices may have an influence on the manifestation of quality parameters. At the Department of Agronomy, Hungarian University of Agriculture and Life Sciences, agronomic impacts on grain yield, protein and lipid content of soybean crop has been studied in a replicated field trial. Nitrogen $(\mathrm{N})$ application and various means of weed control were studied, and grain yields were evaluated in accordance with the treatments. The results obtained suggest, that $\mathrm{N}$ topdressing has positive but no significant effect on grain yield, however, the means of weed control resulted in an almost twofold yield improvement compared to the control. The treatments had diverse effects regarding both protein and lipid contents of the crop yield, however, significant protein and lipid yield improvement of the crop could be observed.

\section{KEYWORDS}

soybean, grain yield, protein yield, lipid yield

\footnotetext{
${ }^{*}$ Corresponding author. Tel.: +36 20859 6880. E-mail: nanirag4646@gmail.com
} 


\section{INTRODUCTION}

Soybean (Glycine max L. Merr) is the most important legume grown worldwide for food production and animal feeds due to its high nutritional values (Sanginga et al., 2002). Protein and lipid are two of the most important nutritional compositions in soybean (Gerde and White, 2008). On the average, protein and lipid together constitute about $60 \%$ of dry soybeans that comprise $40 \%$ of protein and $20 \%$ of lipid (Maleki et al., 2013). Yield and nutritional composition of soybean rely on environmental conditions, type of variety used, and agronomic practices including nutrient and weeds management. Improper nutrient and weeds management can cause a reduction in yield and nutritional composition as well as grain quality.

One of the important nutrients for soybean is nitrogen. Nitrogen $(\mathrm{N})$ is vital for many processes in plants like chlorophyll and protein synthesis. Fageria and Baligar (2005) reported that $\mathrm{N}$ is very important for soybean vegetative growth and optimum biomass. The two main sources of $\mathrm{N}$ for soybean are biologically fixed $\mathrm{N}_{2}$ and mineral $\mathrm{N}$ fertiliser (Salvagiotti et al., 2008). $\mathrm{N}$ fertilisation must be provided if a deficiency in fixed $\mathrm{N}_{2}$ occurs (Miransari, 2016). Many previous studies have been conducted on the $\mathrm{N}$ requirement for different soybean varieties in various areas on yield and seed composition. Among them is a study conducted by Wood et al. (1993), in which they found a positive effect on grain yields of soybean of treatment that used $\mathrm{N}$ fertiliser in different locations. They also found that the response to the $\mathrm{N}$ fertiliser also depended on the type of cultivar and application time. The results of this work suggest that $\mathrm{N}$ fertiliser application is best in a rising proposition. Taylor et al. (2005) reported the same finding that $\mathrm{N}$ application increased seed yield regardless of planting date, variety, or location.

Most studies have shown that $\mathrm{N}$ affects soybean yield in different environments, but no effect of $\mathrm{N}$ on the protein and oil contents of soybean were found, as these contents are influenced by planting date, variety, and cultivation environment. So far, there is a lack of information related to the influence of $\mathrm{N}$ on soybean ES Gladiator variety cultivated on a crop site with brown forest soil. Therefore, this study is important, as the results can be used as a guide for soybean cultivation on the specific soil type.

Weeds management is also very important in soybean cultivation, as soybean has been shown to be sensitive to weed interference during the development of the crop. Weeds can compete for environmental resources and release allelopathic substances. In certain areas, soybean yield loss caused by weeds can reach $80 \%$ if it is not handled properly (Gazziero, 2004). If weeds are not controlled, it will not only interfere with the growth and crop yield, but will also increase the production cost due to the increase in labour costs, agricultural inputs or machinery. According to the study by Marangoni et al. (2013), weed management (weeded, unweeded) greatly influenced soybeans yield. The effect of weed management on different soybean varieties was studied and positive and negative effects on yields were found depending on varieties. However, there is less information on the effect of weeds on yield and seed composition, and especially on the alimentary value of the studied variety in the given environment. Thus, the effects of weeds and the environment on the specific variety are important to be evaluated. 


\section{MATERIALS AND METHODS}

\subsection{Experimental site}

The field experiment was carried out at the experimental site of the Department of Agronomy, MATE in Gödöllö, Hungary $\left(47^{\circ} 46^{\prime} \mathrm{N}, 19^{\circ} 21^{\prime} \mathrm{E}, 242 \mathrm{~m}\right.$ above sea level), on a sandy loam, brown forest soil (Chromic Luvisol) during the 2020 growing season. The experimental site is located in a hilly area in a close to average climatic zone of the country. The year 2020 was exposed to slightly higher precipitation. The annual average precipitation in Hungary was $615 \mathrm{~mm}$ in 2020, while the respective value of Gödöllő was $694 \mathrm{~mm}$ (12.8\% higher). The temperature means of the actual crop year did not differ from the average.

\subsection{Soybean cultivar, plant population, and experimental design}

A soybean variety, ES Gladiator was used in this study, and was planted with a scheduled plant density of 540,000 viable germs on a hectare. The experimental design was a $2 \times 3$ factorial arranged in a split plot design with four replications. In this experimental design, nitrogen fertiliser was assigned to the main plot and weed canopy to the sub-plot.

\subsection{Cultural practices}

The experimental plot was cleared, ploughed, rotor-tilled, and the seedbed was prepared before planting. The basic fertiliser treatments were applied to the experimental field in accordance with the usual practices (Birkás et al., 2004), on the basis of crop requirement. A preemergent weed control was used to eliminate weeds. Soybean seeds were planted at a depth of $3 \mathrm{~cm}$. Eleven weeks after planting, the plants were supplied with $200 \mathrm{~kg} \mathrm{~N} \mathrm{ha}^{-1}$, the control had no nutrient supply. The $\mathrm{N}$ dosage was selected to meet the aims of the study to evaluate the effect of high dose of $\mathrm{N}$ fertiliser on the yield and chemical content of soybean. Weeds were controlled every two weeks according to the weed canopy treatments, which were weedy, hand weeded, and mechanically weeded. The mechanically weeded treatment was done by inter-row hoeing with a rotary machine. The plants were then harvested manually. Planting and harvest dates were respectively 25th May and 7th October.

\subsection{Measurements}

At harvest, all plants in a sampling area of $1.5 \mathrm{~m}^{2}$ per plot were harvested to calculate grains yield. Pods from harvested plants were oven-dried immediately at temperature of $50{ }^{\circ} \mathrm{C}$ for two days for grain yield determination. The dried pods then were hand-threshed, and the grains were weighed to calculate grain yield per plot. The grains were ground for moisture content and chemical composition of protein and lipid determinations using NIR Product Analyzer (INSTALAB 600). The average moisture content of dried grain was $4.65 \%$. The protein and lipid contents were expressed as percentage, and also protein and lipid yields were calculated based on their contents multiplied by dry grain yield.

\subsection{Statistical analysis}

Statistically, a one-way between treatments ANOVA was conducted to compare the effect of the different nutrition supply and weed canopy on grain yield, protein content, lipid content, 
protein yield, and lipid yield. ANOVA was performed at $P=0.05$ level of significance to determine whether the treatments were different. Post hoc comparisons using the least significant difference (LSD) test was made at $P<0.05$. The significance level used in the statistical studies was 5\%. For the statistical evaluation of our results, the Explore and ANOVA modules of the IBM SPSS V.23 software were used.

\section{RESULTS AND DISCUSSION}

There was no statistically significant difference between nutrition groups as demonstrated by one-way ANOVA at the $P<0.05$ level (Table 1) for parameters evaluated including grain yield $[F(1,22)=0.55, P=0.47]$, protein content $[F(1,22)=0.10, P=0.76]$, lipid content $[F(1,22)$ $=0.01, P=0.90]$, protein yield $[F(1,22)=0.54, P=0.47]$, and lipid yield $[F(1,22)=0.39$, $P=0.54]$. There was also no statistically significant difference between weed canopy groups for protein content $[F(2,21)=2.42, P=0.11)$ and lipid content $[F(2,21)=0.73, P=0.49)$ (Table 1). However, there was a statistically significant difference between weed canopy groups for grain yield $[F(2,21)=5.05, P=0.02)$, protein yield $[F(2,21)=4.25, P=0.03)$, and lipid yield $[F(2,21)=5.24, P=0.01)$ (Table 1$)$.

\subsection{Grain yield (g/plot)}

The grain yield was not significantly different between nutrition treatments. However, yield of soybean with the treatment of $200 \mathrm{~kg} \mathrm{~N} \mathrm{ha}^{-1}$ was $14.78 \%$ higher than of the control $\left(0 \mathrm{~kg} \mathrm{ha}^{-1}\right)$. Several previous studies have demonstrated that soybean yields give different responses to $\mathrm{N}$ nutrition. There are studies that show a positive response and there are also those that show a negative response. A study conducted by Wood et al. (1993) in Alabama found that the response of soybean yield to $\mathrm{N}$ nutrition depends on the location of cultivation, the variety used, and also the time of application. There were two out of the seven locations tested that showed a negative response regarding grain yield. Five locations that had a positive effect were also inconsistent in grain yield as there was interaction with soybean cultivar. They also found that grain yield decreased when $\mathrm{N}$ was applied at the plant stage of R5 for all varieties tested. Therefore, they concluded that $\mathrm{N}$ application was not recommended because of the inconsistency of grain yield response.

Similarly, Kaschuk et al. (2016) found that application of $\mathrm{N}$ fertiliser did not cause an increase in yield on the two soybean varieties studied, whether $\mathrm{N}$ fertiliser was supplied at sowing time, during reproductive stages, or both. In contrast, Taylor et al. (2005) in Alabama found that $\mathrm{N}$ application increased seed yield regardless of planting date, variety, or location. $\mathrm{N}$ application of $60-70 \mathrm{~kg} \mathrm{ha}^{-1}$ maximised yield and R1 dry matter accumulation. They concluded that $\mathrm{N}$ can be a viable input for double-cropped soybean at an optimal economic rate of $59 \mathrm{~kg} \mathrm{ha}^{-1}$. Meanwhile, Hatami et al. (2009) in Kashmir found that soybean yield increased significantly with the increasing of $\mathrm{N}$ fertiliser up to $150 \mathrm{~kg} \mathrm{ha}^{-1}$. They also found that not only the grain yield increased, but $\mathrm{N}$ fertiliser promoted dry matter accumulation and plant growth. According to the research done by Mourtzinis et al. (2018) across the United States, grain yield increased when $\mathrm{N}$ fertiliser was used up to $120 \mathrm{~kg} \mathrm{ha}^{-1}$. They tested different rates of $\mathrm{N}$ from 0 to as much as $560 \mathrm{~kg} \mathrm{ha}^{-1}$. 
Table 1. Analysis of variance for grain yield, seed chemical content, and seed chemical yield of soybean as affected by nutrition and weed canopy treatment

\begin{tabular}{|c|c|c|c|c|c|c|}
\hline Parameter & Source of variation & Sum of squares & $\mathrm{df}$ & Mean square & $F$ & Sig. \\
\hline \multirow[t]{8}{*}{ Grain yield (g/plot) } & Nutrition & & & & & \\
\hline & Between groups & 458.50 & 1 & 458.50 & 0.55 & 0.47 \\
\hline & Within groups & 18317.16 & 22 & 832.60 & & \\
\hline & Total & 18775.66 & 23 & & & \\
\hline & Weed canopy & & & & & \\
\hline & Between groups & 6098.77 & 2 & 3049.38 & 5.05 & 0.02 \\
\hline & Within groups & 12676.89 & 21 & 603.66 & & \\
\hline & Total & 18775.66 & 23 & & & \\
\hline \multirow[t]{8}{*}{ Protein content (\%) } & Nutrition & & & & & \\
\hline & Between groups & 0.50 & 1 & 0.50 & 0.10 & 0.76 \\
\hline & Within groups & 113.75 & 22 & 5.17 & & \\
\hline & Total & 114.25 & 23 & & & \\
\hline & Weed canopy & & & & & \\
\hline & Between groups & 21.44 & 2 & 10.72 & 2.42 & 0.11 \\
\hline & Within groups & 92.89 & 21 & 4.42 & & \\
\hline & Total & 114.33 & 23 & & & \\
\hline \multirow[t]{8}{*}{ Lipid content (\%) } & Nutrition & & & & & \\
\hline & Between groups & 0.06 & 1 & 0.06 & 0.01 & 0.90 \\
\hline & Within groups & 86.54 & 22 & 3.93 & & \\
\hline & Total & 86.60 & 23 & & & \\
\hline & Weed canopy & & & & & \\
\hline & Between groups & 5.62 & 2 & 2.81 & 0.73 & 0.49 \\
\hline & Within groups & 80.97 & 21 & 3.86 & & \\
\hline & Total & 86.60 & 23 & & & \\
\hline \multirow[t]{8}{*}{ Protein yield (g/plot) } & Nutrition & & & & & \\
\hline & Between groups & 95.80 & 1 & 95.80 & 0.54 & 0.47 \\
\hline & Within groups & 3905.04 & 22 & 177.50 & & \\
\hline & Total & 4000.84 & 23 & & & \\
\hline & Weed canopy & & & & & \\
\hline & Between groups & 1153.18 & 2 & 576.59 & 4.25 & 0.03 \\
\hline & Within groups & 2847.66 & 21 & 135.60 & & \\
\hline & Total & 4000.84 & 23 & & & \\
\hline \multirow[t]{8}{*}{ Lipid yield (g/plot) } & Nutrition & & & & & \\
\hline & Between groups & 5.27 & 1 & 5.27 & 0.39 & 0.54 \\
\hline & Within groups & 295.86 & 22 & 13.45 & & \\
\hline & Total & 301.13 & 23 & & & \\
\hline & Weed canopy & & & & & \\
\hline & Between groups & 100.26 & 2 & 50.13 & 5.24 & 0.01 \\
\hline & Within groups & 200.87 & 21 & 9.57 & & \\
\hline & Total & 301.13 & 23 & & & \\
\hline
\end{tabular}

df: Degree of freedom; Sig.: Significance; Significance level $=P<0.05$. 
Different grain yield responses to $\mathrm{N}$ application show that the success of $\mathrm{N}$ application on soybean is highly dependent on the variety and also on the cultivation location. The positive response of soybean grain yield to $\mathrm{N}$ fertiliser is probably due to low-nodulation variety or caused by an environmental limitation on soybean growth. Both of these factors have restricted $\mathrm{N}$ fixation, resulting in a positive response to $\mathrm{N}$ fertiliser.

The grain yields of soybean were significantly different for the applied treatments of weed canopy (Fig. 1). Post hoc comparison using the LSD test indicated that mean value for hand weeded $(M=77.28, \mathrm{SD}=25.66)$ significantly differed from weedy $(M=44.54, \mathrm{SD}=28.32)$ and mechanically weeded $(M=42.48, \mathrm{SD}=18.72)$. However, results for weedy canopy did not significantly differ from of the mechanically weeded. According to research done by Marangoni et al. (2013), weed management had a significant effect of on grain yield of soybeans. The yield of soybean in the absence of coexistence with weeds (weeded) was higher compared to the yield of soybean in coexistence (unweeded) with weeds. The yields were reduced by $30 \%$ when no weed control was performed. Similar results were found by Nepomuceno (2007), who evaluated weed interference in soybean in conventional sowing system, and reported a $32 \%$ drop in the yield of the crop when it coexisted with weeds throughout its cycle. Pires (2005) evaluated the competitive potential of soybean cultivars against weeds, and it was observed that all cultivars under the presence of weeds displayed yield reductions of approximately $480 \mathrm{~kg} \mathrm{ha}^{-1}$. As a result of these studies, it is clear that weeds interfere with the yield of soybean. In fact, mechanical weeding, where the stump or root of the weed is still left in the ground, also interferes with the soybean yield. One of the possible reasons behind yield drop are competition between crops and weeds for sources of nutrients, water, and light.

\subsection{Protein and lipid content (\%)}

The results of protein content at different nutrition and weed canopy treatments are shown in Fig. 2. Nutrition supply had no significant effect on protein content, the mean score difference between the two treatments was only $0.63 \%$. According to the results, neither weed canopy

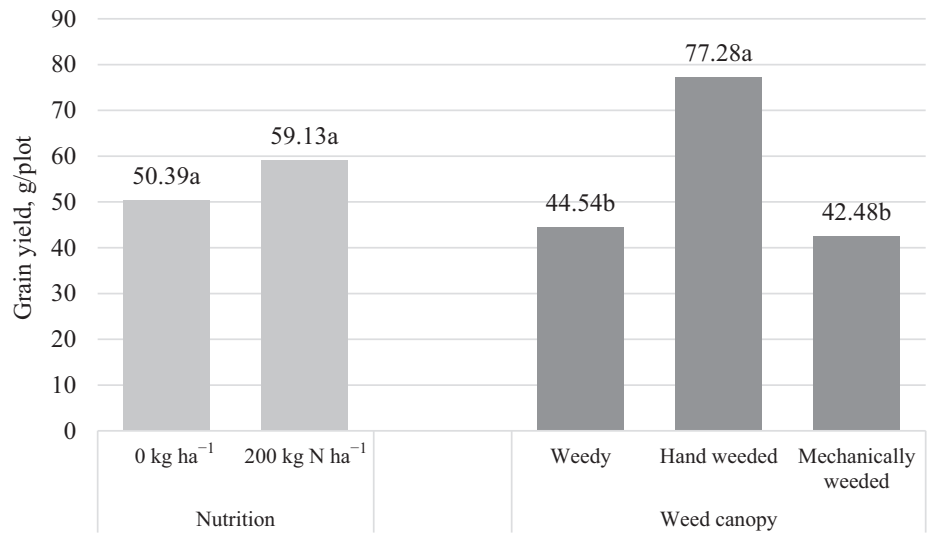

Fig. 1. Effect of nutrition and weed canopy on grain yield (g/plot) of soybean. Means with the same letter are not significantly different from one another by LSD at $P<0.05$ 


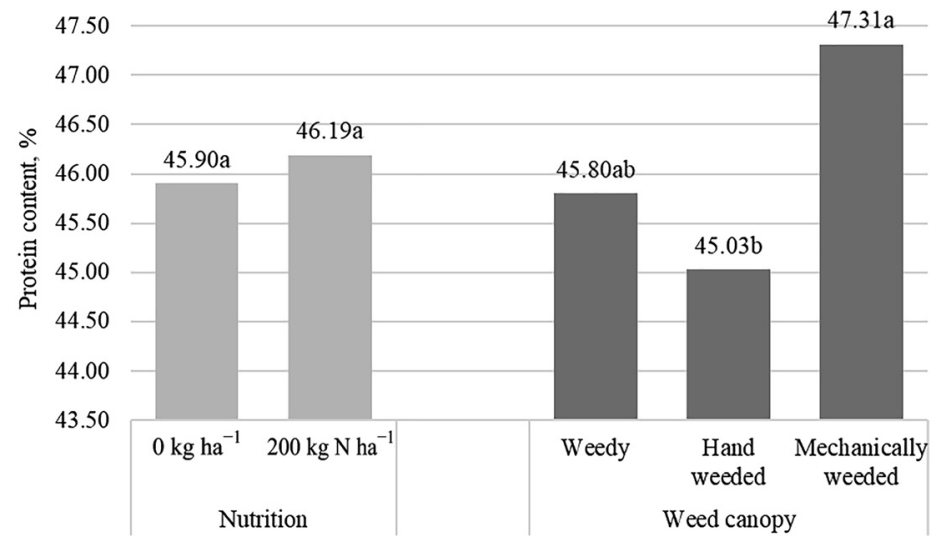

Fig. 2. Effect of nutrition and weed canopy on protein content (\%) of soybean. Means with the same letter are not significantly different from one another by LSD at $P<0.05$

treatment had any effect on the protein content. The LSD test showed that mean score for mechanically weeded $(M=47.31, \mathrm{SD}=2.55)$ was the highest but not significantly different from weedy $(M=45.80$, SD $=1.03)$, which did not significantly differ from hand weeded treatment $(M=45.03, \mathrm{SD}=2.38)$.

The effects of nutrition and weed canopy on lipid content are presented in Fig. 3. There were also no significant differences either between nutrition supplies or weed canopy treatments regarding lipid contents. The mean values of lipid content for no nutrient supply treatment $\left(0 \mathrm{~kg} \mathrm{ha}^{-1}\right)$ and $200 \mathrm{~kg} \mathrm{~N} \mathrm{ha}^{-1}$ supplementation were $12.81 \%$ and $12.72 \%$, respectively. The mean values of lipid content under different treatments of weed canopy were $13.17 \%$ (weedy), $13.04 \%$ (hand weeded), and $12.08 \%$ (mechanically weeded).

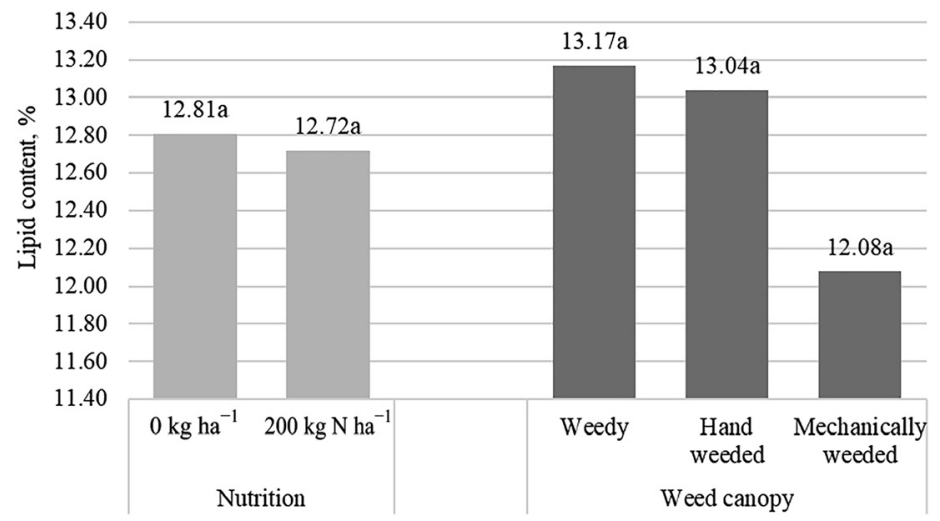

Fig. 3. Effect of nutrition and weed canopy on lipid content (\%) of soybean. Means with the same letter are not significantly different from one another by LSD at $P<0.05$ 
Several previous studies reported similar results for the response of protein and oil or lipid content of soybean to $\mathrm{N}$ fertiliser. According to the research done by Wood et al. (1993), N fertilisation had no significant effect on protein and oil concentrations of six of the seven soy cultivars tested. They indicate that $\mathrm{N}$ fertilisation would not be an effective mean of altering protein and oil concentrations of soybean in Alabama, a selection of cultivars with the desired oil and protein concentrations would be a more reliable method for producing premium soybean based on seed composition.

Taylor et al. (2005) found that $\mathrm{N}$ applied to late-planted soybean in the Deep South, Alabama had no impact either on seed yield and quality or on protein and oil contents. Meanwhile, Kaur et al. (2017) reported that $\mathrm{N}$ application at $179 \mathrm{~kg} \mathrm{ha}^{-1}$ on clay soil reduced seed protein by $1.05 \%$ compared to unfertilised soybeans, however, it increased oil content by $0.7 \%$. Soybean seed composition showed inconsistent responses to $\mathrm{N}$ fertilisation, probably due to climatic conditions, such as lower temperatures and higher precipitation during seed filling may reduce protein and oil concentration, whereas high air temperatures and moderate rainfall at the seed filling period can result in higher protein concentration in soybean seeds (Bennett and Krishman, 2005).

There are limited data on the effect of weeds on protein and lipid contents of soybean. However, there is a study done by Ariunaa et al. (2006) on weed management using chemical control. They found that fat contents in seed were $12.9-18.3 \%$ and the protein contents were 29.9-31.5\%. They found no significant difference between control (unweeded) and chemical control using herbicides on either protein or fat contents. Therefore, the presence of weeds does not affect the protein and fat contents of soybean, the inconsistence in chemical composition may be due to other factors such as environmental limitation like drought or water stress condition. Water stress during the early reproductive stages resulted in a $16 \%$ decrease in seed protein Rotundo and Westgate (2009). However, oil concentrations of two cultivars responded to drought stress in an opposite trend to protein concentration, drought stress increased oil concentration, regardless of $\mathrm{N}$ application and rate (Basal et al., 2020). According to the research done by Peer et al. (2013), weed control methods (weedy, hand weeding, the use of herbicides, integrated hand weeding and herbicide) showed that integrated hand weeding and herbicide recorded comparable lipid content in soybean seed, and the lowest lipid percentage was seen in the weedy plot.

\subsection{Protein and lipid yield (g/plot)}

There were no significant differences in protein yields under different nutritional conditions. The results in Fig. 4 show that the application of $200 \mathrm{~kg} \mathrm{~N}$ ha $^{-1}$ gave $14.69 \%$ higher soybean yield than without nutrient supply treatment. The results also revealed that the protein yields under different weed canopy conditions (Fig. 4) were significantly higher at the hand weeded treatment $(M=35.02, \mathrm{SD}=12.30)$ followed by weedy treatment $(M=20.59, \mathrm{SD}=13.29)$ and mechanically weeded treatment $(M=20.06, \mathrm{SD}=8.88)$. However, there was no significant difference between weedy and mechanically weeded treatments.

The lipid yield of samples showed a similar trend to that of the protein yield (Fig. 5). No significant difference was shown between the nutrition treatments, but a significant difference was shown between the weed canopy treatments. Lipid yield of soybean supplied with $200 \mathrm{~kg} \mathrm{~N} \mathrm{ha}^{-1}$ was $12.71 \%$ higher compared to no nutrient supply condition. Meanwhile, the LSD test results 


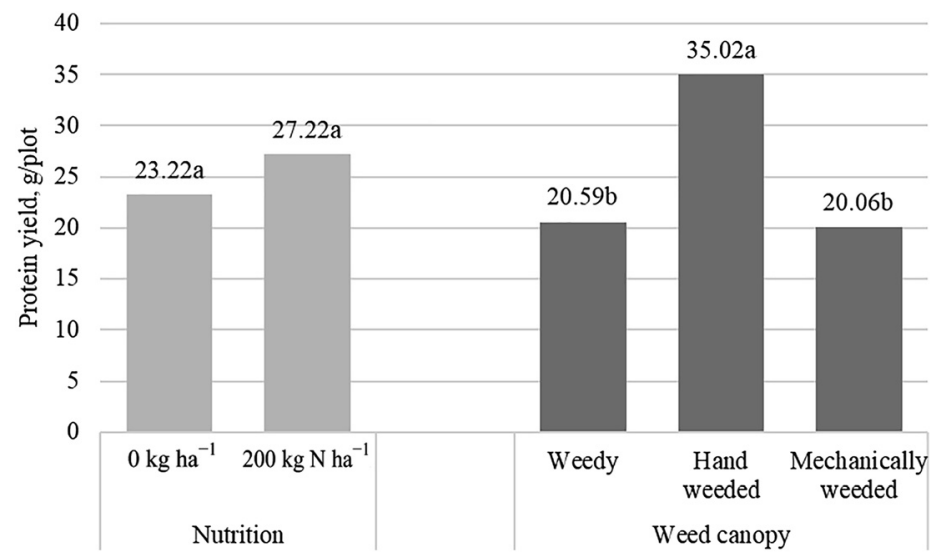

Fig. 4. Effect of nutrition and weed canopy on protein yield (g/plot) of soybean. Means with the same letter are not significantly different from one another by LSD at $P<0.05$

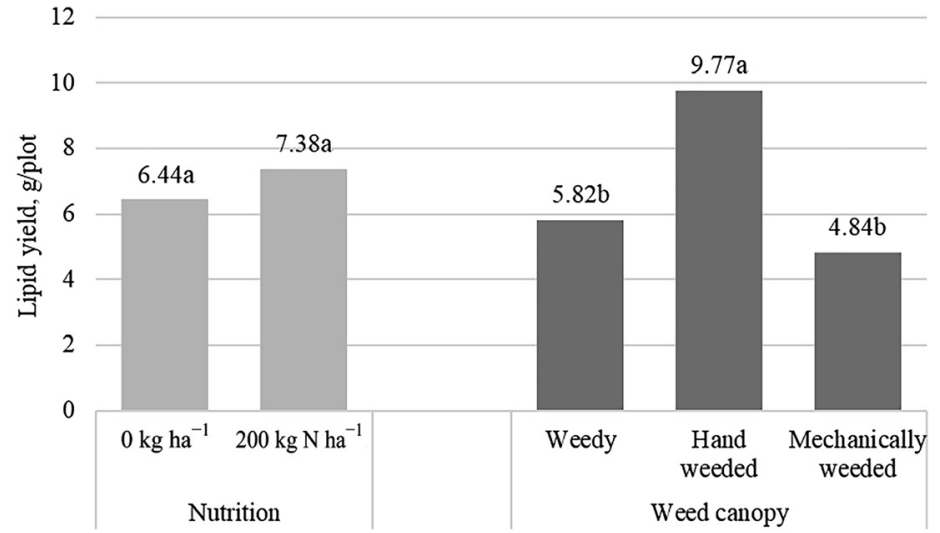

Fig. 5. Effect of nutrition and weed canopy on lipid yield (g/plot) of soybean. Means with the same letter are not significantly different from one another by LSD at $P<0.05$

on weed canopy showed that hand weeded condition $(M=9.77, \mathrm{SD}=3.10)$ provided significantly higher yields than weedy $(M=5.82, \mathrm{SD}=3.55)$ and mechanically weeded conditions $(M=4.84, \mathrm{SD}=2.55)$. However, weedy condition did not significantly differ from the mechanically weeded condition.

Protein and lipid yields were calculated on the basis of concentration multiplied by grain yield. Although the concentrations of protein and lipid did not show significant differences under weed canopy conditions, the high grain yield for hand weeded treatment caused higher protein and lipid yields than for other treatments. Soybean production based on seed composition yield is important for the production of processed food products and oils. 


\section{CONCLUSIONS}

Agronomic impacts on grain yield, protein and lipid contents of ES Gladiator soybean variety have been studied in a replicated field trial at the Gödöllö experimental field, Hungary. N application and various means of weed control were studied, and samples of grain yield were evaluated in accordance with the treatments. The results obtained suggest that $\mathrm{N}$ topdressing had positive, but no significant effect on grain yield, while the means of weed control resulted in an almost twofold yield improvement compared to the control. The treatments had diverse effects on quality parameters, both on protein and lipid contents of the crop yield, however, significant protein and lipid yield improvement of the crop could be observed.

\section{ACKNOWLEDGEMENTS}

This research was supported by the Doctoral Programme of the MATE University. The PhD students involved were sponsored by the Government of Malaysia. The authors would like to express their gratitude to all colleagues and the technical staffs both in field and laboratories for their assistance and valuable contribution to this study.

\section{REFERENCES}

Ariunaa, O., Otgonsuren, M., and Bayarsukh, N. (2016). Effect of chemical weed control of soybean (Glycine max L.) field in Mongolia. International Journal of Advanced Research in Biological Sciences, 3(1): 192-198.

Basal, O. and Szabo, A. (2020). Yield and quality of two soybean cultivars in response to drought and N fertilization. Journal of Tekirdag Agricultural Faculty, 17(2): 203-210.

Bennett, J.O. and Krishnan, H.B. (2005). Long-term study of weather effects on soybean seed composition. Korean Journal of Crop Science, 50(1): 32-38.

Birkás, M., Jolánkai, M., Gyuricza, C., and Percze, A. (2004). Tillage effects on compaction, earthworms and other soil quality indicators in Hungary. Soil and Tillage Research, 78(2): 185-196.

Fageria, N. and Baligar, V. (2005). Enhancing nitrogen use efficiency in crop plants. Advances in Agronomy, 88: 97-185.

Gazziero, D.L.P. (2004). Manejo e controle de plantas daninhas em soja, In: Vargas, L. and Roman, E.S. (Eds.), Manual de manejo e controle de plantas daninhas. Bento Gonçalves \& Embrapa Uva e Vinho, pp. 595-635.

Gerde, J.A. and White, P.J. (2008). Lipids. Soybeans: 193-227.

Hatami, H., Ayenehband, A., Azizi, M., and Dadkhah, A.R. (2009). Effect of N fertilizer on growth and yield of soybean at North Khorasan. Journal of Crop Production, 2(2): 25-42.

Kaschuk, G., Nogueira, M.A., De Luca, M.J., and Hungria, M. (2016). Response of determinate and indeterminate soybean cultivars to basal and topdressing $\mathrm{N}$ fertilization compared to sole inoculation with Bradyrhizobium. Field Crops Research, 195: 21-27.

Kaur, G., Serson, W.R., Orlowski, J.M., McCoy, J.M., Golden, B.R., and Bellaloui, N. (2017). Nitrogen sources and rates affect soybean seed composition in Mississippi. Agronomy, 7(4): 77. 
Marangoni, R.E., Jakelaitis, A., Tavares, C.J., Rezende, B.P.M., Mello Filho, O.L., and Cunha, P.C.R. (2013). Effect of weed interference on soybean cultivars at two sowing times. Planta Daninha, 31(3): 511-519.

Maleki, A., Naderi, A., Naseri, R., Fathi, A., Bahamin, S., and Maleki, R. (2013). Physiological performance of soybean cultivars under drought stress. Bulletin of Environment, Pharmacology and Life Sciences, 2(6): $38-44$.

Miransari, M. (2016). Soybeans, stress and nutrients, In: Miransari, M. (Ed.), Environmental stresses in soybean production, Vol. 2. Soybean Production, pp. 273-298.

Mourtzinis, S., Kaur, G., Orlowski, J.M., Shapiro, C.A., Lee, C.D., Wortmann, C., Holshouser, D., Nafziger, E.D., Kandel, H., and Conley, S.P. (2018). Soybean response to nitrogen application across the United States: a synthesis-analysis. Field Crops Research, 215: 74-82.

Nepomuceno, M. (2007). Períodos de interferência das plantas daninhas na cultura da soja nos sistemas de semeadura direta e convencional. Planta Daninha, 25(1): 43-50.

Peer, F.A., Hassan, B., Lone, B.A., Qayoom, S., Latief Ahmad, B.A.K., Ssingh, P., and Singh, G. (2013). Effect of weed control methods on yield and yield attributes of soybean. African Journal of Agricultural Research, 48(8): 6135-6141.

Pires, F.R. (2005). Potencial competitivo de cultivares de soja em relação as plantas daninhas. Planta Daninha, 23(4): 575-581.

Rotundo, J.L. and Westgate, M.E. (2009). Meta-analysis of environmental effects on soybean seed composition. Field Crops Research, 110(2): 147-156.

Salvagiotti, F., Cassman, K.G., Specht, J.E., Walters, D.T., Weiss, A., and Dobermann, A. (2008). Nitrogen uptake, fixation and response to fertilizer N in soybeans: a review. Field Crops Research, 108(1): 1-13.

Sanginga, N., Okogun, J., Vanlauwe, B., and Dashiell, K. (2002). The contribution of nitrogen by promiscuous soybean to maize based cropping in the moist savannah of Nigeria. Plant and Soil, 241: 223231.

Taylor, R.S, Weaver, D.B., Wood, C.W., and Van Santen, E. (2005). Nitrogen application increases yield and early dry matter accumulation in late-planted soybean. Crop Science, 45(3): 854-858.

Wood, C.W., Torbert, H.A., and Weaver, D.B. (1993). Nitrogen fertilizer effects on soybean growth, yield, and seed composition. Journal of Production Agriculture, 6(3): 354-360.

Open Access. This is an open-access article distributed under the terms of the Creative Commons Attribution 4.0 International License (https://creativecommons.org/licenses/by/4.0/), which permits unrestricted use, distribution, and reproduction in any medium, provided the original author and source are credited, a link to the CC License is provided, and changes - if any - are indicated. (SID_1) 